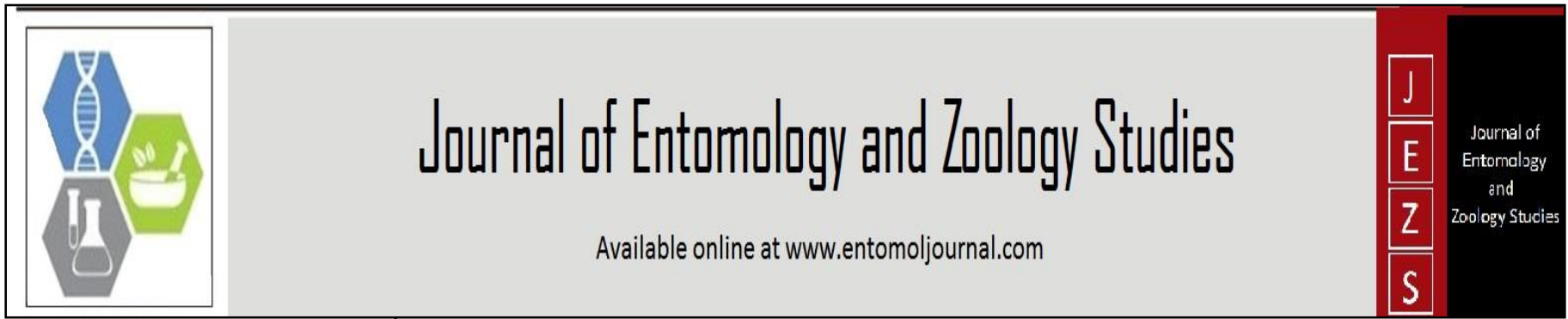

E-ISSN: 2320-7078

P-ISSN: 2349-6800

www.entomoljournal.com

JEZS 2020; 8(5): 1212-1220

(C) $2020 \mathrm{JEZS}$

Received: 25-07-2020

Accepted: 27-08-2020

\section{Md. Abdul Ahad}

Professor, Department of

Entomology, Faculty of

Agriculture, Hajee Mohammad

Danesh Science \& Technology

University, Dinajpur-5200,

Bangladesh
Corresponding Author:

Md. Abdul Ahad

Professor, Department of

Entomology, Faculty of

Agriculture, Hajee Mohammad

Danesh Science \& Technology

University, Dinajpur-5200,

Bangladesh

\title{
Seven non-darwinian theories opposite to evolution
}

\section{Md. Abdul Ahad}

DOI: https://doi.org/10.22271/j.ento.2020.v8.i5q.7677

\section{Abstract}

The objective of this article is to prove that "Seven non-Darwinian theories opposite to evolution". However, the genetic drift represents the punctuated equilibrium, the shifting balance theory, the allopatric speciation theory and the species selection theory for the macroevolution. The genetic drift rapidly works in a small and isolated population and not works in a large population. Hence, genetic drift means small and isolated population and vice-versa. But the genetic drift creates zero variation. But there is no variation (raw materials of any kind of evolution); there is no evolution. Hence, evolutionary biologists rejected genetic drift for any kind of evolution. Again, genetic drift means small and isolated but those populations have to mate with their close relative and produced homozygous organisms. Homozygous organisms have low fecundity, suffer from various diseases, least fitted to survive and may extinct suddenly, e.g. American Heath hen. Thus, small populations and isolated populations (i.e. genetic drift) are opposite to any kind of evolution, even risk for extinction. However, genetic drift is also the key force of Neutral theory, which works in smalls and isolated populations. Consequently, Neutral theory is opposite to any kind of evolution. So, many evolutionary biologists rejected Neutral theory. Once more, evolutionary biologists rejected the shifting balance theory, the punctuated equilibrium theory and of Goldschmidt's theory. Gould and Wright advocated chromosomal speciation (chromosome rearrangements) theory for macroevolution but which are not valid. Moreover, extinction is the main process of the macroevolution, which is quite absurd. The fossil is the excellent and only evidence of those theories of macroevolution. But fossil completely opposes macroevolution. So, those seven nonDarwinian theories are opposite to any kind of evolution. Consequently, the Darwinists, the neoDarwinists and the Sociobiology's oppose those non-Darwinian. Subsequently, plants and animals including human are not evolved via those theories.

Keywords: Genetic drift, small and isolated population, macroevolution, Gould and Eldridge, Wright's rule, Goldschmidt, Kimur

\section{Introduction}

Evolution suggests that life arose by natural process from non-living materials and achieved its present diversity including man ${ }^{[1]}$. Darwin defines evolution as descent with modification through natural selection from a few common ancestors [2] in this way: unicellular organism/bacterium $\rightarrow$ invertebrate $\rightarrow$ lung fish $\rightarrow$ amphibian $\rightarrow$ reptile $\rightarrow$ placental mammal $\rightarrow$ higher mammal $\rightarrow$ human ${ }^{[3-5]}$

In 1931, Sewall Wright (Professor, Chicago University) invented genetic drift. In 1932, Wright provided its diagram as 'Adaptive landscape model' for macroevolution ${ }^{[6-9]}$. In 1982, Wright declared that "From time to time, however, a species is represented with vacant niches. This precipitates evolutionary change of a different order of magnitude, those that constitute macroevolution. Wright used Goldschmidt's hopeful monster theory and chromosomal speciation theory to support macroevolution through his theory and claimed that fossil support his theory [10]; elaborated document would be placed later. Adaptive landscape model is probably the most common metaphor in evolutionary genetics ${ }^{[11]}$. This theory is regarded as a cornerstone of modern evolutionary ${ }^{[12]}$. It is a very complex model that was never developed in evolutionary biology ${ }^{[13]}$.

In 1972 and 1977, two American paleontologists, Stephen J. Gould (Professor, Harvard University) and Niles Eldredge (Professor, Natural History Museum) developed the punctuated equilibrium theory ${ }^{[15-17]}$. They declared that all the animals and plants arose suddenly by macroevolution (Gould and Eldredge) ${ }^{[16]}$. Even the $20^{\text {th }}$ century is for the punctuated equilibrium ${ }^{[18]}$. At the Chicago meeting (1980)-it is declared that gradual/microevolution is change within a species, this is an adaptation it is not an evolution. 
But macroevolution must always lie at the heart of evolutionary theory. Without macroevolution, evolution does not occur ${ }^{[19]}$. In addition, allopatric speciation is a speciation that occurs in small and isolated population ${ }^{[20]}$. It is claimed that the punctuated equilibrium theory was borrowed from allopatric theory (theory of Mayer, German scientists) of macroevolution of Mayr ${ }^{[21,22]}$. Gould and Eldredge frequently used the shifting balance theory (as Wright's rule), the allopatric speciation and the species selection theory (USA, scientists), Goldschmidt's theory (hopeful monster theory and chromosomal speciation theory. The fossil of the genera Hyopsodus, Haplomylus, Pelycodus and the fossil of horse support the punctuated equilibrium theory ${ }^{[16]}$. However, those theories of macroevolution reject the Darwin's theory and the neo-Darwinian theory (Ahad) ${ }^{[14]}$. Therefore, those theories are known as non-Darwinian theory. However, it is verified the genetic drift is the key force of those theories, which rapidly work in small and isolated population. It is established that the genetic drift represents the small and isolated population, the shifting balance theory (Wright's rule), the punctuated equilibrium theory, the allopatric speciation theory, the species selection theory and vice-versa; if any one able to prove that genetic drift unable to produce new species or rejected the shifting balance theory and fossil does not support macroevolution but support gradual evolution; then those theories would be opposite to evolution/invalid automatically (Ahad) ${ }^{[14]}$. Therefore, there is a great scope to verify whether those non-Darwinian theories of macroevolution are opposite to evolution or not.

The Neutral theory of molecular evolution was introduced by the Japanese evolutionary biologist Kimura in 1968; and independently by two American evolutionary biologists King and Jukes in 1969 and described in detail by Kimura in his monograph in1983. According to the neutral theory a neutral mutant allele can arise within a population and their fate is largely determined by random genetic drift, rather than by selective advantage in finite population; (small and isolated population) in forming the genetic structure of biological populations and provides a benefit for the molecular evolution (Kimura) ${ }^{[25,26]}$. Thus, the genetic drift and finite populations are the key forces of the neutral theory and it is a non-Darwinian theory. However, evolutionary biologists rejected the neutral theory. For example: The accumulated evidence from the past 50 years that natural selection has played the predominant role in shaping withinand between-species about genetic variation. As a consequence, the neutral theory has been overwhelmingly rejected by bilogist ${ }^{[27]}$. As the random genetic drift and small and isolated population are the key forces of the neutral theory. Moreover, this theory is rejected by many evolutionary biologists plus it is a non-Darwinian theory. So, there is a great chance to further verify whether the neutral theory is opposite to evolution or not.

Therefore, the aim of this article is to prove those seven nonDarwinian theories of evolution are opposite to evolution or not. Therefore, to work on the aim is very importance and there is no alternative way but to work on this objective. This article would be helpful to the Darwinists, neo-Darwinists, Sociobiology's and who dealing with the evolution.

\section{Both genetic drift and small and isolated population} opposite to any kind of evolution

The genetic drift rapidly works in a small and isolated population and not works in a large population. For this reason, genetic drift means small and isolated population. But both the genetic drift and the small and isolated population are opposite to any kind of evolution:

\subsection{Genetic drift opposite to any kind of evolution}

The following literatures proved that the genetic drift creates zero variation. But there is no variation (raw materials of any kind of evolution):

a) Mutations refill the variations, which are lost by genetic drift, leading to the state of mutation-genetic drift balance ${ }^{[7}$, ${ }^{28]}$. In addition, the random genetic drift results in the accumulation of fixed populations lacking in genetic variability (Smith) ${ }^{[29]}$. As a result, genetic drift creates zero variation and this issue is established mathematically ${ }^{[7,28]}$. So, genetic drift produces zero variation. But "there no variability, there is no evolution ${ }^{[30]}$.

b) Many evolutionary biologists declared that any kind of evolution is quite impossible by the effects of genetic drift: i) the importance of genetic drift in species formation is currently under intensive study and question also ${ }^{[31]}$ ii) How important the effect of genetic drift/founder effect in nature is still unknown ${ }^{[30]}$ iii) The role of genetic drift in the evolution of an organism has become a subject for debate ${ }^{[32]}$. iv) Due to the genetic drift, population shows higher degree of homozygosity, which is poorly adapted and becomes evolutionary blind alleys ${ }^{[33]}$. v) How does the genetic drift produce a new species is controversial. There are many biologists who denied the importance of it has any evolutionary function (Hickman) ${ }^{[34]}$. vi) The importance of genetic drift is quite difficult to evaluate ${ }^{[35]}$. vi) Genetic drift plays a relatively negligible role in evolution (Wilson et al., 1977) ${ }^{[36]}$. vii) Most of Wright's contemporaries noted that drift act as a nondirective and non-additive force of evolution $[37,38]$.

Hence, it is documented that many evolutionary biologists declared that any kind of evolution is quite impossible by the effects of genetic drift.

c) Genetic drift changes the allele frequencies randomly in a small and isolated population ${ }^{[20]}$. Hence, the alternate term of

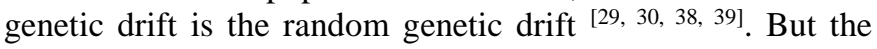
gene frequency or the sequence of a base of gene must be changed in a well planned way of a smoothly operating system of an organism, which is highly coordinated structure and its production requires innumerable variations of just at the right degrees, in right place and at the right time. But genetic drift randomly changes the gene frequency or the sequence of a base of gene, which is very harmful of an organism or at best would be neutral to effect $[7,37,40,41,42,43]$. Thus, genetic drift randomly changes the gene frequency, which is very harmful of an organism.

\subsection{Smalls and isolated populations opposite to any kind of evolution}

Genetic drift means small and isolated population and viceversa. Again, small and isolated population means the sifting balance theory and the punctuated equilibrium and vice-versa (Ahad, 2017) ${ }^{[14]}$. But the following literatures proved that the smalls and isolated populations create zero variation and thus any kind of evolution is not possible by the smalls and isolated populations:

a) The effect of random genetic drift in a small population produce homozygous organism and it is mathematically proved by the fixation index equitation ${ }^{[29]}$.

b) Small and isolated human populations have to inbreed and 
consequently those human populations suffer from numerous diseases: If two cousins are married, they have got an idiot child. In state of nature, the idiot would die in competition with the normal one before it reaches the reproductive age. As a result, today, there are laws in all civilized countries against the marriage of very close relatives (Altenburg, 1970) ${ }^{[44]}$. In addition, inbreeding is vital; particularly to human pedigree, because those have recessive diseases (e.g. the albino) are the products of mating between relatives from consanguineous mating ${ }^{[45]}$. Additionally, Reddi ${ }^{[46]}$ declared that the diseases observed in the offspring of consanguineous marriages include sickle cell anemia, congenital heart diseases, diabetes, hypertension, coronary heart disease cystic fibrosis etc. ${ }^{[47]}$. The decline of population fitness due to inbreeding- seems to be a nearly universal phenomenon ${ }^{[45]}$. As a result, Purves and Orians ${ }^{[30]}$ declared that the spread of deleterious alleles by drift occurs most readily in small population by the genetic drift.

Hence, small and isolated human populations have to inbreed and produce homozygous human. Consequently, those human populations suffer from various diseases.

c) Small and isolated animals have to inbreed that increase homozygosity and consequently those animals suffer from various diseases and a few documents are place here:

Genetic drift is mimics to inbreeding by increasing homozygosity ${ }^{[29]}$. Inbreeding increase the juvenile mortality rates of hippopotamus, cheetah elephant and other wild animal ${ }^{[45]}$. In all domestic bird species inbreeding has been shown to cause a decline in traits affecting reproduction and viability ${ }^{[48}$ and ${ }^{49]}$. The arctic rabbit and the lemming suffer periodically plunge due to small and isolated population ${ }^{[33]}$.

d) Numerous experiments with small population size oppose any evolution in those populations: i) During a 35-year study of small population size in prairie chickens, population size decreased gradually due to low fertility and low hatching rates of eggs and reduced survival fitness ${ }^{[50]}$. Scientific experiments and observations carried out in recent years have revealed that being in a restricted population is not an advantage for the theory of evolution from the genetic point of view, but rather a disadvantage ${ }^{[51]}$. Multiple studies with small populations showed that those populations have extremely negative effects on survival and reproduction ${ }^{[52]}$. Consequently, it is justified that recent experiments with small population size oppose any kind of evolution. f) Most breeding populations of animals are usually small ${ }^{[32,34]}$. In addition, the living world is constantly evolving, without any future/goals [30]. Therefore, if existing plants/animals or some of those have been evolved spontaneously and abruptly (suddenly) through those theories of macroevolution; then newer species of plants/animals could be found suddenly now and then at any area of the world. "But there is no known such reference about spontaneously and sudden/gradual appearance of any new species either artificially or naturally $[3,4]$."

g) Small and isolated populations may extinct suddenly. Because of genetic drift, small and isolated population is under a great threat of extinction. As that populations show no genetic variations; without variation the whole population, no matter how large, is extremely susceptible to diseases and environmental changes. So, the Alaskan northern elephant seal (Callorhinus ursinus), African cheetah (Acinonyx jubatus), European buffalo/wisent, Pere David's deer may extinct suddenly ${ }^{[20,45]}$; its best example is that the extinction of American heath hen in 1930 (Wallace) ${ }^{[53]}$.

Hence, small and isolated animals have to inbreed that increase homozygosity and consequently those animals suffer from various diseases even may extinct suddenly.

Hence, it is verified that both the genetic drift and the small and isolated population creates zero variation. But there is no variation (raw materials of any kind of evolution); there is no evolution and thus those are opposite to any kind of evolution. As it is established that the genetic drift represents the small and isolated population, the shifting balance theory (Wright's rule), the punctuated equilibrium theory, the allopatric speciation theory, the species selection theory and vice-versa; consequently, those theories are opposite evolution. In addition, genetic drift and small and isolated populations is also another key force of Neutral theory of molecular evolution ${ }^{[23,24]}$. Thus, Neutral theory of molecular evolution is also opposite to evolution.

\section{Wright himself included drift as an agent of neo- Darwinism and many evolutionary biologists declared that the punctuated equilibrium theory is also an agent of neo-Darwinism}

Both the genetic drift (shifting balance theory) and the punctuated equilibrium theory are the agents of neoDarwinism (i.e. an agent of microevolution). Moreover, isolation (i.e. small populations) is also an agent of neoDarwinism and there are documents but a few are set here:

Genetic drift is an agent of neo-Darwinism [33, 38, 39, 26] and isolation also ${ }^{[26,39,54]}$. Additionally, Dennett ${ }^{[55]}$ and Dawkins [56] declared that the punctuated equilibrium theory lies firmly within the neo-Darwinian synthesis (as genetic drift). Furthermore, Darwin included isolation (means small and isolated population/finite population) as a factor of gradual change (evolution); but not sudden change (Darwin) ${ }^{[57]}$."

\section{Modern breeders and Wright himself unable to produce a single new species though Wright's process}

Wright (the originator of shifting balance theory) declared that: i) "Local inbreeding with slight, occasional crossbreeding and thereafter selection produce rapidly new species [6]". ii) "Wright studied the effects of close inbreeding and cross breeding on guinea pigs during 1915-1925 at US Bureau of Animal Industry [10]". Thus, Wright was a breeder life time. But he was unable to develop an animal species. Furthermore, modern breeders are also unable to produce a single new species following the Wright's process $\left.{ }^{[3}, 4,43,58\right]$ but produced some varieties or races. However, those variety or races back to the parental type by random mating.

\section{Extinction is the main process of the macroevolution, which is quite absurd}

Wright (the originator of shifting balance theory) noted: The world underwent extinction of many forms, including the dinosaurs at the end of the Mesozoic period, which opened the way for the enormous expansion of the mammals during the Paleocene and later [10]. Gould and Eldredge (the originator of punctuated equilibrium theory) noted: Extinction, it is said, inevitably over takes overspecialized taxa $[16,17,59]$. Brewer and Sing provides a figure how extinction produces suddenly new species through the macroevolution to support the punctuated equilibrium theory (Brewer and Sing) ${ }^{[38]}$.

Oppositely, extinction of living organism never produces a new species as: i) At present 24-100 species are losing per day due to human activities ${ }^{[60]}$; over the past three and a half centuries, nearly 200 animal species have become extinct in 
the USA (Kaskel et al.) ${ }^{[61]}$. In addition, the recently extinct fifteen animals are: Passenger pigeon, Cormorant, Carolina Parakeet, Great auk, Dodo, Canary Islands, Caspian tiger, Tasmanian wolf, Quagga, Bubal Hartebeest, Pyrenean Ibex, golden toad, Tecopa pupfish, Sea cow and Baiji dolphin ${ }^{[62]}$.

But there is no evidence that those extinct species produce any new species, even a new breeds/variety/race during or thereafter extinction. Instead the 'Bio-diversity conservation law' is developed to protect the extinction of wild and domestic species. This law is practices worldwide, which clearly indicated that no new species had evolved through the extinction of living organisms.

As macroevolution occurred through the punctuated equilibrium, the shifting balance theory, the allopatric speciation theory and the species selection theory, Goldschmidt's theory (hopeful monster theory and chromosomal speciation); so, those theories are opposite to any kind of evolution and not valid.

6. The fossil is the excellent and only evidence of both punctuated equilibrium theory and the shifting balance theory but fossil does not support the macroevolution

Gould and Eldredge (the originator of punctuated equilibrium theory) exercised fossil of Hyopsodus (13 times), Haplomylus, Pelycodus and horse to support of macroevolution under their model punctuated equilibrium ${ }^{[16]}$. For example: i) We concentrate on Gingerich's data for Hyopsodus and argue that it provides an excellent example of species selection under our model ${ }^{[16]}$. ii) Fossil of Haplomylus and Pelycodus to support punctuated equilibrium theory ${ }^{[16]}$. v) Evolution of horse supports the punctuated equilibrium model ${ }^{[16]}$.

Similarly, Wright (the originator of shifting balance theory) acknowledged that fossil support macroevolution: i) The more indifferent ones drift about through a wide range of frequencies in the course of geologic time ${ }^{[9]}$. ii) The fossil of horse holds up the macroevolution through genetic drift ${ }^{[6]}$. iii) The morphological differences between many higher taxa, as seen in the fossil record, are such that those could only have arisen abruptly. This issue has recently been raised again by Gould and Eldredge ${ }^{[10]}$. Thus, the fossil is the excellent and only evidence of both shifting balance theory and the punctuated equilibrium theory.

Oppositely, the fossil of Hyopsodus, Haplomylus, Pelycodus and horse do not support the macroevolution and the documents are placed in various subheadings:

\subsection{Fossil of Hyopsodus mammals do not support the macroevolution}

i) Hyopsodus fossil in Eocene strata (in Wyoming spanning) record a period of 5 million years, a branching phylogeny, which exhibits the gradual phyletic evolution, the overall size increase with iterative evolution of small species and character divergence was following the origin of each new lineage ${ }^{[63]}$. ii) When all of the samples of Hyopsodus can be placed in stratigraphic position, those are so ordered, the pattern of change in tooth size indicates its emergence is one of continuous gradual change within lineages, with gradual divergence following the separation of new sister lineages [64] and a more complete picture of Hyopsodus gradual evolution is based on additional collection [65]. Young noted that the commonest early Eocene mammal Hyopsodus became differentiate into several distinct species by the gradual changes in size of tooth (by fossil collection) and the most probably of the whole animal (Young) ${ }^{[66]}$.

Though, Gould and Eldredge used Gingerich's data indicating macroevolution of Hyopsodus to support their model; so, it is not true. The misinterpretation occurs about the usage of Gingerich's data as then "Gingerich's (1977) article was in a press ${ }^{[16]}$. Therefore, the reviewers and also the editors had no way to verify it. Therefore, the contradiction between Gingerich's literature and Gould and Eldredge's literature is found.

So, Hyopsodus's fossil does not support the macroevolution but support the gradual one.

\subsection{Fossils of Haplomylus and Pelycodus do not support the macroevolution}

Fossils of Haplomylus and Pelycodus do not support the macroevolution:

i) Stippling in illustrates the hypothesis of gradual change that most closely fits the observed stratigraphic of Haplomylus. The study of evolutionary rates in the Haplomylus speirianus-to $H$. scottianus lineage shows that this lineage has a temporal scaling slope of rates significantly lower than -0.5 . This means that tooth size (and, by inference, overall body size) increased non-randomly and directionally through time in the lineage. There is a random component of change in all of these examples. But superimposed on this, Haplomylus shows a significantly nonrandom component of directional [67]. ii) The fossil of the genera Hyopsodus, Haplomylus, Pelycodus, and Plesiadapis are placed in the stratigraphic context. The resulting patterns of evolution at the species level illustrate the importance of gradual phyletic evolution in the origin of new species and the consistent presence of gradual morphological divergence following the geographic speciation (geographic speciation seems best characterized as parapatric rather than allopatric in these examples) ${ }^{[65]}$.

iii) From the studied cranial anatomy of fossil record of Plesiadapidae (mammalia, primate), the evolution of these species (Hyopsodus, Haplomylus and Pediculus, Plesiadapis) was both gradual and continuous, supporting the Darwinian model of gradual phyletic evolution. No evidence was found to suggest a "Punctuated equilibrium" pattern of phylogeny [68]. iv) Stratigraphic records of Early Eocene Pelycodus in northwestern Wyoming shows that the continuous, gradual connection between successive species and the reversed trend toward smaller tooth size in Pelycodus frugiuorus with the appearance of $P$. jarrouii. Other characters available for the study in this sequence, such as mesostyle development, shows the same pattern of gradual evolutionary change, but mesostyle development continues progressively through the whole sequence and does not show the character divergence seen in tooth size ${ }^{[64]}$.

Therefore, fossils of Haplomylus and Pelycodus do not support the macroevolution but support the gradual one.

\subsection{The fossils of horse (Equus sp.) do not support the macroevolution but support the gradual one}

Fossil of horse does not support the macroevolution and the authentications are place here:

i) The fossils of horse indicate gradual evolution (Parker aand Haswell) ${ }^{[69]}$. ii) The evolution of horse is gradual ${ }^{[70]}$. iii) The careful consideration of the fossil of horse-material suggests that evolution of horse could have proceeded by gradual changes ${ }^{[66]}$. iv) Fossil record indicates that the evolution of horses occurred in a regular progressive ${ }^{[32,71]}$. vi) The series 
of fossil tracing out the development of horse from Eocene to recent times provide clear evidence of evolution is the gradually increase of body size ${ }^{[36]}$.

Thus, it could be concluded that the fossil of horse does not support the macroevolution but support the gradual one. In addition, it could be noted that the evolution of horse has been the excellent example of mammalian evolution in the fossil record ${ }^{[64]}$; yet the fossil of horse does not support the macroevolution.

Wilson et al. acknowledged that the reading from the fossils archives suggests that the macroevolution is a very gradual process (Wilson et al.) ${ }^{[36]}$; so, according to Wilson et al. the fossil archives suggest the gradual evolution. Prothero acknowledged that in the past few decades, many new discoveries have provided the numerous transitional fossils that show the evolution of hoofed mammals (cattle, goat, deer etc) from their primitive ancestors. Similarly, it is documented that the gradual evolution of the even-toed artiodactyls occurred from their earliest roots and their great radiation into pigs, peccaries, hippos, camels, and ruminants (Prothero, 2009) ${ }^{[72] .}$

Genetic drift is the key force, even represents the shifting balance theory (Wright's rule), the punctuated equilibrium theory, allopatric speciation theory and species selection theory ${ }^{[14]}$. But the effects of the genetic drift are difficult to observe in fossil, and so its existence has frequently been denied by the paleontologists (Birdsell) ${ }^{[73]}$; it indicated that opposed macroevolution.

Therefore, it is confirmed that though the fossil (the fossil of Hyopsodus, Haplomylus, Pelycodus and horse) and other fossil do not support the macroevolution but support the gradual one. As macroevolution (sudden change) in fossil is the excellent and only one evidence of the punctuated equilibrium theory, the shifting balance theory, the allopatric speciation theory and the species selection theory, Goldschmidt's theory (hopeful monster theory and chromosomal speciation); so, those theories have no evidence in fossil and thus those are opposite evolution.

7. Both shifting balance theory and the punctuated equilibrium theory advocated long period of stasis after rapid evolutionary change but it is not accepted by the modern evolutionary biologists

It is verified that both the shifting balance theory and the punctuated equilibrium theory advocated the long period of stasis after rapid evolutionary change ${ }^{[14]}$. But stasis (nochange) and sudden evolutionary change are not accepted by modern evolutionary biologist ${ }^{[51,74-76]}$.

\section{Both Wright and Gould updated the rejected theory of Goldschmidt's as the shifting balance theory and the punctuated equilibrium theory, respectively}

In "The Material Basis of Evolution", Goldschmidt proposed his theory (Goldschmidt) ${ }^{\text {[77] }}$. But it claimed that Wright and Gould updated those rejected theory of Goldschmidt's as the shifting balance theory and the punctuated equilibrium theory, respectively ${ }^{[10-78]}$."

But Goldschmidt's theory is rejected by modern evolutionary biologists and a few documents put at this point:

i) Michael R. Dietrich acknowledged that Goldschmidt is remembered today as one of the most controversial biologists of the twentieth century, as his rejection of the classical gene and his unpopular theories (macromutation/ hopeful monster/ saltational evolution) about macroevolution, which significantly damaged his scientific reputation (Dietrich) ${ }^{[79]}$. Additionally, Goldschmidt's mechanism, involved "systemic mutations", rejection the classical gene concept and is no longer considered by most modern scientists [80]. Goldschmidt's "Saltation (systemic mutation and developmental macromutations)" is now almost universally regarded as biologically impossible ${ }^{[81]}$. In addition, the early neo-Darwinian synthesis theorists had rejected hopeful monsters due to lack of evidence ${ }^{[56]}$. Furthermore, hopeful monsters were disparaged on the grounds that even if a big change in the phenotype could occur as a result of a mutation, the hopeful monster would be a novelty on its own with no possibility of finding a mate. Without a mate; there would no new species (Baeson) ${ }^{[82]}$.

Hence, it is legalized that both Wright and Gould updated the Goldschmidt's theory and developed their theory. But evolutionary biologists rejected the Goldschmidt's theory; consequently, evolutionary biologists rejected Wright's and Gould's theory.

9. Wright and Gould and Eldridege advocated chromosomal speciation (chromosome evolutionary biologists rejected rearrangements) theory for macroevolution but which are not valid

Literatures of Wright (Originator of shifting balance theory) ${ }^{[10]}$ and Literatures of Wright Gould and Eldridege (Originator of punctuated equilibrium theory) ${ }^{[16,76,78]}$ indicated that they advocated chromosomal speciation theory (chromosome rearrangement/chromosomal aberration/ chromosomal mutations or genome doubling) for macroevolution.

In opposition, any kind of changes in chromosome number/ chromosome rearrangement very harmful to living organism and the documents are placed here:

Recent investigation of chromosome number (karyotype) in somatic cells of pigs and dogs revealed that anomalies are generally represented by monosomy $(2 n-1)$ or trisomy $(2 n+1)$, and both types of mutations are decidedly harmful to those organisms. Moreover, most of the heteroploid of birds (or poultries) are lethal during their early embryonic development and cause early abortion. In human, most chromosomal aberration are frequent in spontaneous abortion and about $50 \%$ of all spontaneous abortions occur in human within 3 month's of pregnancy in USA. What is more, irregularities in number of human chromosomes such as a loss of one or the gain of one or more chromosomes have been associated with numerous abnormal syndrome such as Turner syndrome (sterile female), Edward syndrome, Triplex female (substerile and mentally retarded), Klinefelter syndrome (sterile male and mentally retarded), Patau syndrome (mental deficiency and deafness). As a result, chromosome number cannot be changed without producing any harmful effect. As a consequence, an aneoploid organism suffers from a specific genetics imbalance. A few specific changes in chromosomal structure have been found to be linked to certain type of cancer such as a translocation to chromosome 9 related to the cancer chronic myeloid leukemia [3, 4, 5]. Additionally, chromosomal deficiencies have been observed in corn and other seed plants, and causes pollen sterility. Plants with chromosomal translocation and inversion also suffer from pollen and ovule sterility. In addition, as a general rule in most plants, pollen grains containing deficiencies or duplication are nonviable and aborted (Ahad and Ferdous) ${ }^{[4,}$ 5]. 
Changes in chromosome number also occur through hybridization. But hybridization between two plants species or between two animal species is quite impossible either naturally or artificially; if imposed, the fertilization fails, if the fertilization is successful, the embryo may abort, or the young may suffers various abnormalities and at last it may die. If the hybrid survives to maturity, it must be sterile due to chromosome number doubling/genome doubling (Ahad) ${ }^{[3-5] \text {. }}$ Above literatures indicated that due to changes of chromosome number, rearrangement and structure (chromosomal speciation) living organisms suffered various diseases and abnormalities, which created great problem to live them and thus any kind of evolution is quite impossible through chromosomal speciation.

10. Gould was a strong Marxist and he developed a theory that matches and fulfils the requirement of political ideology of Marxism

The literatures of (Perez) ${ }^{[83]}$, (Martin) ${ }^{[84]}$, (Sunderland) ${ }^{[85]}$, (MacDonald) ${ }^{[86]}$, (Pinker) ${ }^{[87]}$ indicated that that Gould (the originator of punctuated equilibrium theory) was a strong Marxist. So, he developed the punctuated equilibrium theory to fulfill the requirement of political ideology (sudden change) of Marxism. But how a theory, which is a political ideology, be a theory of evolutionary biology?

11. Evolutionary biologists rejected both the shifting balance theory and the punctuated equilibrium

World renowned evolutionary biologists rejected both the shifting balance theory and the punctuated equilibrium theory:

\subsection{World renowned evolutionary biologists rejected the} shifting balance theory and the punctuated equilibrium.

Numerous World renowned evolutionary biologists rejected evolution of a new species by the "shifting balance theory" and a few mentioned here:

i) Recent field experiments of ecological genetics by Cook and Jones ${ }^{[88]}$, Goulson and Owen ${ }^{[89]}$, Jones [90], Skipper [91] rejected shifting balance theory. Those researchers confirmed that genetic drift had no value for evolution in small and isolated populations but natural selection had. Thus, most of Wright's contemporaries noted the drift as nondirected and nonadaptive of evolution ${ }^{[92]}$ and is the most controversial among the evolutionary geneticists ${ }^{[93,94]}$ ii) In 1997, Coyne et al. [95] evaluated Wright's shifting balance theory of macroevolution, examining both the theoretical issues and the relevant data from the nature and the laboratory. They concluded that the genetic drift is often unnecessary for movement between the peaks. Furthermore, in 2000, Coyne et al. published another article on the validity and importance of Wright's shifting balance theory. Their review of both the theory and data led them to reject the idea of Wright's theory. However, instead of shifting balance theory, they supported the view of Darwin (as quantified by Fisher) ${ }^{[96]}$. Hence, it is documented that evolutionary biologists rejected genetic drift/ the shifting balance theory.

\subsection{Rejection of punctuated equilibrium theory by world renowned evolutionary biologists}

Numerous literatures indicated that world renowned evolutionary biologists rejected the punctuated equilibrium theory but a few are placed here:

i) In punctuated equilibrium theory Gould and Eldredge use analogy and metaphor constitutes a non-scientific discourse attempting to validate a scientific theory ${ }^{[97]}$. ii) Top most USA paleontologist Gingerich recommendation eight questions to readers of punctuated equilibrium theory such as: How do you recognize 'punctuation'? How do you recognize stasis? How are they scaled to measure of macroevolution? etc. ${ }^{[98]}$ ? iii) Punctuated equilibrium has been severely criticized by evolutionary biologists because: stable lineages in fossil records not absolutely static and sole base on fossil record a theory could not develop as fossil sequences incomplete ${ }^{[11]}$. The punctuated equilibrium theory adds little to evolutionary theory, neither in paleontology nor in the field of population ecology. Moreover, based only on sole paleontological evidence, a theory of evolutionary biology cannot develop ${ }^{[99]}$. v) In reality, Gould and Eldredge offered no truly original and genuinely significant contributions to evolutionary theory by the Punctuated equilibrium theory ${ }^{[80]}$. vi) The punctuational nature of punctuated equilibrium has engendered perhaps the most confusion theory in evolutionary biology ${ }^{[100]}$. vii) There are several points (such as the socalled "Cambrian Explosion) irony related to punctuated equilibrium that have little to do with the science and a great deal to do with the assumptions of the scientists ${ }^{[52]}$. viii) Gould has come to be seen by non-biologists by the punctuated equilibrium theory (Maynard-Smith) ${ }^{[101]}$. Hence, world renowned evolutionary biologists rejected the punctuated equilibrium theory.

Therefore, it is verified that world renowned evolutionary biologists rejected both the shifting balance theory and the punctuated equilibrium theory.

As, the genetic drift represents the punctuated equilibrium theory, the shifting balance theory (Wright's rule), the allopatric speciation theory, the species selection theory and vice-versa ${ }^{[14]}$; hence, those theories are rejected by World renowned evolutionary biologists automatically.

\section{Evolutionary biologists rejected Neutral theory of molecular evolution}

i) The neutral theory was supported by unreliable theoretical and empirical evidence from the beginning, and that in light of modern genome-scale data this theory has been overwhelmingly rejected its universality (Kern and Hahn) [102]. Again, equilibrium between mutation and drift, is a central tenet of the neutral theory (Kimura and Ohta) ${ }^{[103]}$; but the fact that polymorphism is correlated with recombination implies that in almost every species examined, at almost every locus, there has recently been a selected allele nearby (whether advantageous or deleterious), such that levels of polymorphism are not at mutation-drift equilibrium (Kern and Hahn) ${ }^{[102]}$. ii) In recent years, however, many population geneticists have challenged the views of the neutral theory by reporting that a high proportion of amino acid substitutions are caused by positive selection. These results are mainly based on newly developed statistical methods such as Bayesian approaches for identifying positively selected codon sites and the MK test applied to genome wide analysis. A critical review of these statistical methods has shown that theoretical foundation of neutral theory is not well established and they often give false-positive and false-negative results (Nei et al.) ${ }^{[104]}$; similarly there are at least twelve (12) different tests, which indicated natural selection has played the predominant role in shaping within-and between-species about genetic variation at the DNA level. Thus, the neutral theory has been amazingly rejected ${ }^{[105]}$. iv) Over the past decade, both empirical data and theoretical advances have 
sufficiently accumulated to suggest that adaptive evolution is not mutation-limited in natural populations but natural selection have [106, 107]. Many authors claimed that both empirical data and theoretical advances have sufficiently accumulated to suggest that genetic drift and small population size have no adaptive value but natural selection have ${ }^{[108-111]}$. Thus, according to numerous evolutionary biologists neutral theory is opposite to any kind of evolution.

\section{Conclusions}

It is verified that the genetic drift represents the small and isolated population, the punctuated equilibrium theory, the shifting balance theory (Wright's rule), the allopatric speciation theory and the species selection theory of macroevolution; if anyone proves that the genetic drift is unable to produce a new species or rejected the shifting balance theory and fossils do not support macroevolution but support the gradual evolution.; then those theories would be opposite to evolution /invalid automatically ${ }^{[14]}$.

The genetic drift rapidly works in a small and isolated population and not works in a large population. But it is proved that both the genetic drift and the small and isolated population are opposite to any kind of evolution. Again, biologists rejected the shifting balance theory and also the punctuated equilibrium theory. Once more, it is confirmed that fossils do not support the macroevolution but support the gradual evolution. So, those theories of macroevolution are opposite to evolution. In addition, Gould and Wright advocated chromosomal speciation (chromosome rearrangements) theory for macroevolution but which are opposite to any kind of evolution. About similar opinion is provided by Ahad ${ }^{[12]}$. Again, the genetic drift is also key force of the neutral theory of molecular evolution. Thus, the neutral theory of molecular evolution is opposite to evolution." That's why; seven non-Darwinian theories are opposite to evolution. As, Darwin's theory is the central theme of biology and also all the theories of evolution [1113 and 114]. Consequently, Darwinists, neo-Darwinists and Sociobiology's are opposing those non-Darwinian theories. Thus, the conclusion is all correct.

\section{Acknowledgement}

The author is grateful for the great help of Google, Research Gate $\left(\mathrm{R}^{0}\right)$, Academia. edu, LinkedIn, Scribd for the data use in this article. The author is also very thankful to the writers and the publishers that mentioned in the references section for using their information in this article.

\section{References}

1. Buffaloe ND. Principles of Biology. Prentice Hall Inc., New Jersey, 1963.

2. Darwin C. The Origin of Species. Oxford University Press, London, 1859.

3. Ahad MA. Artificial selection/hybridization (the main force of evolution) opposite to Darwin's theory and also opposite to macroevolution through chromosomal aberration/ chromosomal number mutation. Martinia. 2015; 6(2):53-67.

4. Ahad MA, Ferdous ASMA. Impossible of macroevolution of new species via changing of chromosome number mutation and structural mutation (Invalid chromosomal speciation Theory): Darwin's Theory and Neo-Darwinian Theory Oppose it. Martinia. 2015; 6(2):68-74.
5. Ahad MA. Criticisms of organic evolution and its evidences. PhD. Thesis, Department of Zoology, Jhangir Nagar University, Savar, Dhaka, Bangladesh, 2006.

6. Wright $S$. The Roles of Mutation, Inbreeding, Crossbreeding, and Selection in Evolution. Proceedings of the Sixth Annual Congress of Genetics. 1932; 1:356366.

7. Gardner EJ, Simmons MJ, Snustad DP. Principles of Genetics, $8^{\text {th }}$ edn. John \& Wiley and Sons, Inc., New York, 1991.

8. Tamarin R. Principles of Genetics, $7^{\text {th }}$ edn. Wadsworth Publishing Co., Belmont, California, 2002.

9. Wright S. Evolution in Mendelian Populations. Genetics. 1931; 16:97-159.

10. Wright S. The shifting balance theory and macroevolution. Ann. Rev. Genet. 1982; 16:1-20.

11. Futuyma DJ. Evolutionary Biology, Sinauer Associates, Massachusetts, 1998.

12. Wade M, Goodnight CJ. Perspective: The Theories of Fisher and Wright in the Context of Metapopulations; When Nature Does Many Small Experiments. Evolution. 1998; 52(6): 1537-1553.

13. Svensson E, Calsbeek R. The Adaptive Landscape in Evolutionary Biology. Oxford University Press, 2013.

14. Ahad MA. Punctuated equilibrium theory represents shifting balance theory (of macro and quantum evolution) and invalid Darwin's theory. J Ent. Zool. Stud. 2017; 5(3):06-12

15. Eldredge N, Gould SJ. Punctuated equilibria: an alternative to phyletic gradualism. In Schopf TJM. (ed.), Models in Paleobiology. Freeman Cooper, San Francisco, 1972, 82-115.

16. Gould SJ, Eldredge N. Punctuated Equilibria: The Tempo and Mode of Evolution Reconsidered. Paleobiology. 1977; 3(2):115-151.

17. Gould SJ. Is a new and general theory emerging? Paleobiology. 1980; 6(1):119-130

18. Gould SJ, Eldredge N. Punctuated equilibrium comes of age. Nature, 1993; 366:223-227.

19. Anonymous. 1980. [www.pathlights.com/ce_encyclopedia/Encyclopedia/20h ist12.htm].Creation-evolution encyclopedia.

20. Starr C, Taggart R. Biology, the Unity and Diversity of Life, $5^{\text {th }}$ edn. Wardsworth Publishing Co. Belmont, California, 1989.

21. Mayr E. Systematics and Origin of Species. Colombia University Press, New York, 1942.

22. Mayr E. Animal Species and Evolution. Belknap Press of Harvard Univ. Press; Cambridge, Mass, 1963.

23. Kimura M. Evolutionary rate at the molecular level. Nature. 1968; 217:624-26.

24. King JL, Jukes TH. Non-Darwinian evolution. Science. 1969; 164:788-98.

25. Kimura M. The Neutral Theory of Molecular Evolution. Cambridge, UK: Cambridge University Press, 1983.

26. Ohta T. The nearly neutral theory of molecular evolution. Annu. Rev. Ecol. Syst. 1992; 23:263-286.

27. Mathew LA, Jensen JD. Evaluating the ability of the pairwise jointsite frequency spectrum to co-estimate selection and demography. Front Genet. 2015; 6:268.

28. Simmons MJ, Snustad DP. Principles of Genetics, $8^{\text {th }}$ edn. John \& Wiley and Sons, Inc., New York, 2000.

29. Smith RL. Ecology and Field Biology, $4^{\text {th }}$ edn. Harper Collins Publishers, New York, 1990. 
30. Purves WK, Orians GH. The Science of Biology, ${ }^{2 n d}$ edn. Sinauer Associates Inc. Publishers, Snderland, Massachuetts, 1987.

31. Russell PJ. Genetics, $5^{\text {th }}$ edn. The Benjamin-Cummins Publishing Co., Inc., Menlo Park, USA, 1998.

32. Rastogi VB. Organic Evolution. Keder Nath Ram Nath, Meerut, New Delhi, 1994.

33. Dodson EO. Evolution: Process and Product. Affiliated East West Press Pvt. Ltd., New Delhi, 1960.

34. Hickman CP. Integrated Principles of Zoology, $4^{\text {th }}$ edn. The C.V. Mosby Co., Saint Lois, 1970.

35. Strickberger MW. Genetic, $2^{\text {th }}$ edn.Macmillianpublishing, London, 1976.

36. Wilson EO, Eisner T, Brriggs WR. Life. Sinaur Associates, Inc. Publishers, Sunderland, Mass, 1977.

37. Wolfe SL. Biology, the Foundations, $2^{\text {nd }}$ edn. Wardsworth Publishing Co. Belmont, California, 1983.

38. Brewer GJ, Sing CF. Genetics. Addison-Wesley Publishing Co., London, 1983.

39. Reif, Wolf-Ernst, Junker T, Hoßfeld U. The synthetic theory of evolution: general problems and the German contribution to the synthesis. Theory Biosci. 2000; 119:41-91.

40. Sinnott WE, Wilson KS. Botany: Principle \& Problems, 6th edn. McGraw-Hill Book Co., New York, 1963.

41. Stanley M, Andrykovitch G. Living: An Introduction to Biology. Addison-Wiley Publishing Co., California, 1984.

42. Maciejouski J, Zieba J. Genetics and Improvement, Part B. Stock Improvement Methods. Elsevier Scientific Publishing Co., Oxford, New York, 1982.

43. Ranganathan BG. Origins? The banner of truth trust. Carlisle, USA, 1988.

44. Altenburg E. Genetics, rev. edn. Oxford and IBH Publishing Co., New Delhi, 1970.

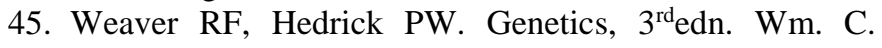
Brown Publishers, England, 1997.

46. Reddi OS. Understanding Genetics. Allied Publishers Limited, New Delhi, 1992.

47. Ayala FJ, Kiger Jr JA. Modern Genetics. The Benjamin Cummings Publishing Co., Inc., California, 1980.

48. Woodard AE, Abplanalp H, Pisenti JM, Snyder LR. Inbreeding effects on reproductive traits in the ringnecked pheasant. Poultry Sci. 1983; 62:1725-1730.

49. Crawford WC. Breeding and selection by poultry fanciers. In: Crawford, R.D. (Ed.), Poultry Genetics. Elsevier, Amsterdam, 1990.

50. Westemeier RL, Brawn JD, Simpson SA, Esker TL, Jansen RW, Walk JW et al. Tracking the long-term decline and recovery of an isolated population. Science, 1998; 282:1695-1697.

51. Soulé ME, Mills LS. Enhanced: No need to isolate genetics, Science, 1998; 282:1658.

52. Anonymous. What is the theory of punctuated, 2017. equilibrium?[https://www.gotquestions.org/punctuatedequilibrium.html]. Last visited 13.03.17.

53. Wallace RA. Biology, the world of life, $5^{\text {th }}$ edn. Harper Collins Publishers Inc., New York, 1990.

54. Stebbins GL. Process of Organic Evolution. PrenticeHall, Englewood Cliffs, New Jersey, 1966.

55. Dennett D. Darwin's Dangerous Idea. Simon and Schuster, New York, 1995.

56. Dawkins R. The Blind Watchmaker. WW. Norton Co., New York, 1996.
57. Darwin C. The Origin of Species, $6^{\text {th }}$ edn. Oxford University Press, London, 1872.

58. Allard RW. Principles of Plant Breeding. John Wiley and Sons, Inc., New York, 1960.

59. Mallet J. Speciation in the 21 st century Speciation by J.A. Coyne and H. Allen. Orr. Sinauer Associates Inc., Massachusetts, USA; 2004. Reviewed of book by J Mallet. Heredity, 2005; 95:105-109.

60. Mader S. Inquiry into life. Wm. C. Brown Publishers, England, 1997.

61. Kaskel A, Hummer Jr PJ, Daniel PJ. Biology: An Everyday Experience. Glencoe division of McGraw-Hill publishing Co., New York, 1992.

62. Anonymous. 2017a.

[Listverselistverse.com/2009/07/25/10-recently-extinctanimals]. Last visited 13.03.17.

63. Gingerich PD. Stratigraphic record of early Eocene Hyopsodus and the geometry of mammalian phylogeny. Nature, 1974; 248:107-109.

64. Gingerich PD. Patterns of evolution in the mammalian fossil record. In: Hallam, A. (ed.). Patterns of Evolution. Elsevier; Amsterdam, 1977.

65. Gingerich PD. Paleontology and phylogeny: Patterns of evolution at the species level in early Tertiary mammals. Am. J Sci., 1976a; 276:1-28.

66. Young JZ. The Life of Vertebrate, $3^{\text {rd }}$ edn. Oxford University Press, New Delhi, 1981.

67. Gingerich D. New species of Apheliscus, Haplomylus, and Hyopsodus (Mammalia, Condylarthra). Paleontology. 1994; 29(6):119-134.

68. Gingerich PD. Cranial anatomy and evolution of early tertiary Plesiadapidae (maammalia, primate). Univ. Mich. Pap. Paleontol. 1976b; 15:1-140.

69. Parker TJ, Haswell WA. A Text Book of Zoology Vol.II., $7^{\text {th }}$ edn. Low Price Publications, New Delhi, 1990.

70. Arms K, Camp PS. Biology: A journey into life. W. B. Saunders Company, New York, 1980.

71. Weisz PB, Keogh RM. The Since of Biology. $5^{\text {th }}$ Edn. McGraw-Hill Book Company, New York, 1982.

72. Prothero DR. Evolutionary transitions in the fossil record of terrestrial hoofed mammals. Evo Edu Outreach. 2009; 2:289-302.

73. Birdsell JB. Human Evolution: An Introduction to the New Physical Anthropology, 2 ${ }^{\text {nd }}$ edn. Rand Mc. Naly College Publishing Co., Chicago, 1975.

74. Mayr E. Speciational Evolution or punctuated equilibria . In The Dynamics of Evolution (eds. Somit, A. and Peterson, S.), Cornell Univ. Press, 1992, 21-48.

75. Batten DD. Punctuated equilibrium: come of age? J Creat. 1994; 8(2):131-137.

76. ReMine WJ. The Biotic Message: Evolution versus Message. St. Paul, Minnesota, 1993.

77. Goldschmidt R. The Material Basis of Evolution. New Haven, Conn., Yale Univ. Press. 1940, 436.

78. Gould SJ. The Return of Hopeful Monsters. Nat. Hist. 86 (June/July): 22-30; Reprinted in "The Panda's Thumb". W. W. Norton \& Co., New York, 1980a, 186-193

79. Dietrich MR. Nat. Rev. Genet. 2003; (4):68-73.

80. Theissen G. Homeosis of the angiosperm flower: Studies on three candidate cases of saltational evolution. Palaeodiversity. 2010; 3:131-139

81. Carroll J. Literary Darwinism: Evolution, human nature, and literature. Taylor \& Francis Group 711, Third Avenue 2 Park Square, Milton Park New York, NY 
10017, 2004.

82. Baeson P. Sudden Changes in Ontogeny and Phylogeny in Gary Greenberg, Ethel Tobach Behavioral Evolution and Integrative Levels: The T.C. Schneirla Series, 1984,

83. Perez M. Evolutionary Activism: Stephen Jay Gould, the New Left and Sociobiology. Endeavour. 2013; 30(10):18.

84. Martin Z. What is the evidence that Gould was a Marxist? [creation.com/what-is-the-evidence-that-gouldwas-a], 2006.

85. Sunderland LD. Darwin's Enigma. Published by Master Book Publishers, Santee, California, 1988.

86. MacDonald KB. The Culture of Critique: An Evolutionary Analysis of Jewish Involvement in Twentieth-Century Intellectual and Political Movements, Praeger, 1998.

87. Pinker S. The Blank Slate. Penguin, New York, 2002.

88. Cook LM, Jones D. The Medionigra Gene in the Moth Panaxia dominula: The Case for Selection. Biol. Sci., 1996; 351(1347):1623-1634

89. Goulson D, Owen D. Long-Term studies of the Medionigra polymorphism in the moth Panaxia dominula: A Critique. Oikos, 1997; 80:613-617.

90. Jones D. Temperatures in the cothill habitat of Panaxia (Callimorpha) dominula L. (the scarlet tiger moth). Heredity, 2000; 84:578-586.

91. Skipper RA, Jr. The Persistence of the R. A. FisherSewall Wright Controversy. Biol. and Phil., 2002; 17:341-367.

92. Singh RS, Uyenoyama MK. (ed.). The Evolution of Population Biology. Cambridge University Press. 2009.

93. Chouteau M, Angers B. Wright's Shifting Balance Theory and the Diversification of Aposematic Signals. PLoS ONE, 2012; 7(3):e34028. doi:10.1371.

94. Johnson GB. The Living World, $3^{\text {rd }}$ edn. McGraw Hill Co., New York, 2008.

95. Coyne JA, Nicholas BH, Turelli M. Perspective: A Critique of Sewall Wright's Shifting Balance Theory of Evolution. Evolution, 1997; 51: 643-671.

96. Coyne JA, Barton NH, Turelli M. Is Wright's shifting balance process important in evolution? Evolution; 2000; 54(1):306-317.

97. Scott H. "Stephen Jay Gould and the Rhetoric of Evolutionary Theory". Rhetoric Review, 2007; 26(2):120-141.

98. Gingerich PD. Reviewed by Gingerich, P. D of Stephen Jay Gould: Punctuated equilibrium (2007). Harvard University Press, 2007.

99. Lichtenstein BM. Evolution or transformation: A critique and alternative to punctuated equilibrium. Academy of Management Annual Meeting Proceedings. 1995; (1):291-295.

100. Hanegraaff H. The Face That Demonstrates the Farce of Evolution. Nashville, TN: Word Publishing, 1998, 40-45.

101. Maynard Smith J. Genes, mems, and minds. The New York Review of book. 1995; 42:46-48.

102. Kern AD, Hahn, MW. The Neutral Theory in Light of Natural Selection. Mol. Biol. Evol. 2018; 35(6):1366137.

103. Kimura M, Ohta T. Protein polymorphism as a phase of molecular evolution. Nature. 1971; 229(5285):467-469.

104. Nei M, Suzuki Y, Nozawa M. The Neutral Theory of Molecular Evolution in the Genomic Era. Annu. Rev. Genomics Hum. Genet. 2010; 11:265-89.
105. Kreitman M. Methods to detect selection in populations with applications to the human. Annu. Rev. Genomics Hum. Genet. 2000; 1:539-59.

106. Sheehan S, Song YS. Deep learning for population genetic inference. PLoS Comput Biol. 2016; 12(3):e1004845.

107. Schrider DR, Kern AD. Soft sweeps are the dominant mode of adaptation in the human genome. Mol Biol Evol. 2017; 34(8):1863-1877.

108. Fay JC, Wyckoff GJ, Wu CI. Testing the neutral theory of molecular evolution with genomic data from Drosophila. Nature; 2002; 415(6875):1024-6.

109.Begun DJ, Holloway AK, Stevens K, Hillier LW, Poh YP. Population genomics: whole genomeanalysis of polymorphism and divergence in Drosophila simulans. PLoS Biol. 2007; 5:e310.

110.Shapiro JA, Huang W, Zhang C, Hubisz MJ, Lu J, Turissini DA et al. Adaptive genetic evolution in the Drosophila genomes. PNAS. 2007; 104(7):2271-6.

111.Akey JM. Constructing genomic maps of positive selection in humans: where do we go from here?. Genome Research. 2009; 19(5):711-22.

112.Ahad MA. Punctuated equilibrium theory, shifting balance theory, allopatric speciation theory and species selection theory for macroevolution valid or not. International J Bot. Studies. 2019; 4(2):92-99.

113. Alters S. Biology, Understanding Life, 2ndedn. Mosby, St. Lois, 1996.

114.Ahad MA. The survival of the fittest is not valid: Darwin's theory of natural selection, the origin of species and the descent of man opposite to evolution. International J Ent. Res. 2020; 5(3):57-64. 